\title{
Eoarchean to Mesoarchean crustal evolution of the northern São Francisco Craton, Brazil: geochronological and isotopic perspectives.
}

\author{
MR. RAFAEL GORDILHO BARBOSA ${ }^{1}$, ROMMULO \\ VIEIRA CONCEICAO ${ }^{2}$, FELIPE PADILHA LEITZKE ${ }^{3}$, \\ JOHILDO BARBOSA ${ }^{4}$, JONAS TUSCH ${ }^{5}$, CARSTEN \\ MÜNKER $^{6}$ AND ALANIELSON C D FERREIRA ${ }^{7}$ \\ ${ }^{1}$ Federal University of Rio Grande do Sul \\ ${ }^{2}$ UFRGS-PPGGEO-LAGEPE \\ ${ }^{3}$ LGI - UFRGS \\ ${ }^{4} \mathrm{NGB}$ - Federal University of Bahia \\ ${ }^{5}$ University of Cologne \\ ${ }^{6}$ Universität zu Köln \\ ${ }^{7}$ Universidade Federal do Rio Grande do Sul \\ Presenting Author: rafab.geologia@gmail.com
}

Precambrian crust generation was a complex and long-lived process, associated with several events of destruction and recycling, which can be verified via geochronological studies, combined with isotopic data, experimental petrology and, also, geodynamic modelling.

The northern part of the São Francisco Craton (SFC) spans a large record of crustal growth, from the Eoarchean until the Neoproterozoic [1]. The basement of this craton is represented by tonalite-trondhjemite-granodiorite (TTG) rocks, gneisses, mafic-ultramafic rocks, Greenstone Belts and metavolcanosedimentary sequences. Noteworthy, this section of the SFC comprises rocks from some of the oldest geological records in South America [2]. Although previous studies already investigated these Archean units, some geochronological constraints are still contradictory and current isotope datasets incomplete.

In addition to traditional tools employing long-lived radiogenic isotope systems $\left({ }^{147} \mathrm{Sm}-{ }^{143} \mathrm{Nd}, \mathrm{Rb}-\mathrm{Sr}\right.$, Lu-Hf), our work intends to provide new isotopic data for the short-lived ${ }^{142} \mathrm{Nd}$ and ${ }^{182} \mathrm{~W}$ in order to better constrain the early crustal evolution of the SFC. In this sense, we present a compilation of all isotopic data produced for the northern SFC up-to-present date and the use of this information to identify possible mechanisms of Archean crustal evolution in the region.

[1] Barbosa, J.S.F., Luciano, R.L., Cruz Filho, B.E., Santana, J.S., Gordilho Barbosa, R., Moraes, A.M.V. 2020. Mapa tectônico-geocronológico da Bahia - implicações metalogenéticas. CBPM-CPRM. 1 Map. Scale: 1:1.000.000.

[2] Oliveira, E.P., McNaughton, N.J., Zincone, S.A., Talavera, C. 2020. Birthplace of the São Francisco Craton, Brazil: Evidence from 3.60-3.64 Ga Gneisses of the Mairi Gneiss Complex. Terra Nova 00: 1-9. 